\title{
First records of four exotic slugs in Argentina
}

\section{Diego E. Gutiérrez Gregoric ${ }^{1,2}$, Ariel A. Beltramino ${ }^{1,3}$, Roberto E. Vogler ${ }^{1,2}$, María G. Cuezzo ${ }^{2,4}$, Verónica Núñez ${ }^{1,2}$, Suzete R. Gomes ${ }^{5}$, Marisol Virgillito ${ }^{6}$, and Sergio E. Miquel ${ }^{2,6}$}

\author{
${ }^{1}$ División Zoología Invertebrados, Museo de La Plata, Facultad de Ciencias Naturales y Museo, Universidad Nacional de La Plata, Paseo del \\ Bosque s/n, B1900WFA, La Plata, Argentina \\ ${ }^{2}$ Consejo Nacional de Investigaciones Científicas y Técnicas (CONICET) \\ ${ }^{3}$ Agencia Nacional de Promoción Científica y Tecnológica (ANPCyT) \\ ${ }^{4}$ Instituto de Biodiversidad Neotropical, Facultad de Ciencias Naturales, Universidad Nacional de Tucumán, Miguel Lillo 205, CP 4000, \\ Tucumán, Argentina \\ ${ }^{5}$ National Malacology Laboratory, USDA APHIS PPQ NIS, Academy of Natural Sciences, 1900 Benjamin Franklin Parkway, Philadelphia, \\ PA, U.S.A., 19103-1101 \\ ${ }^{6}$ División Invertebrados, Museo Argentino de Ciencias Naturales Bernardino Rivadavia, Av. Ángel Gallardo 470, (1405), Buenos Aires, \\ Argentina \\ Correspondence, Diego E. Gutiérrez Gregoric: dieguty@fcnym.unlp.edu.ar
}

\begin{abstract}
This paper reports for the first time the occurrence of four exotic terrestrial slug species in Argentina: Lehmannia valentiana (Férussac, 1823) (Limacidae), Deroceras invadens Reise et al. 2011 (Agriolimacidae), Arion intermedius Normand, 1852 (Arionidae) and Meghimatium pictum (Stolyczka, 1873) (Philomycidae). The study is based on specimens deposited in museums in Argentina. Both the morphologic characteristics and the mitochondrial cytochrome oxidase I gene sequences were used to identify the exotic species. Phylogenetic analyses were also carried out in order to explore the location of their origins. Lehmannia valentiana had the oldest records and has been widely distributed in Argentina. Deroceras invadens and A. intermedius were found to be restricted to the southern portion of the country. Meghimatium pictum was recorded in the northwest and northeast Argentina, and the DNA sequences analyzed from this species were more closely related to specimens from the west of the Strait of Taiwan. A determination of the origin of the other species was impossible because either the sequences analyzed grouped with samples from different geographical origins or only few sequences were available for comparison. In view of the invasive potential of these slug species, the present work provides new and potentially useful DNA sequence data obtained from morphologically-confirmed specimens. Information provided from these analyses should assist in making a rapid identification of these exotic slugs by nonspecialists and governmental authorities who are responsible for managing and controlling the presence of exotic species.
\end{abstract}

Key words: Lehmannia valentiana, Deroceras invadens, Arion intermedius, Meghimatium pictum, molecular phylogenetic analyses

Biologic invasions, together with climate change and habitat fragmentation, constitute one of the most serious threats affecting the maintenance of global biodiversity (Vitousek et al. 1996, Nentwig 2007). Bioinvasions have mostly caused disruptive effects on native species, alteration of ecological processes, changes in natural systems, and economic and human-health problems (Mooney et al. 2005). In South America, for example, certain invasive mollusk species - e.g., the continental bivalve Limnoperna fortunei (Dunker, 1857), the marine gastropod Rapana venosa (Valenciennes, 1846) and the terrestrial snail Achatina (Lissachatina) fulica Bowdich, 1822 - have been reported to reduce biodiversity (Darrigran and Damborenea 2006, Giberto et al. 2006, Thiengo et al. 2007). Some introductions have been deliberate (e.g., A. fulica), while others were unintentional (e.g., L. fortunei), with the latter being the most common case in point (Cowie and Robinson 2003).

Twenty-three exotic terrestrial gastropod species have been reported in Argentina (Parent and Miquel 1999, Miquel et al. 2007, Rumi et al. 2010, Gutiérrez Gregoric et al. 2011).
Six of these species are slugs: Limacus flavus Linnaeus, 1758, Limax maximus Linnaeus, 1758, Deroceras agreste (Linnaeus, 1758), Deroceras laeve (Müller, 1774), Deroceras reticulatum (Müller, 1774), and Milax gagates (Drapaurnaud, 1801) (Rumi et al. 2010). Because of the high intraspecific morphologic variability in slugs, molecular studies have proven to be extremely useful for species identification (McDonnell et al. 2008, 2011). Phylogenetic studies conducted on several species have, moreover, enabled a more complete understanding of the history of the invasions and an establishment of the origins of the invaders along with the pathways of their introduction (e.g., Facon et al. 2003). These molecular studies, combined with anatomical taxonomic identification and an understanding of those pathways, constitute crucial information for enabling governmental entities to adjust their strategies for controlling invading species (Cowie and Robinson 2003, Lizarralde et al. 2008).

The aim of this report is to document for the first time in Argentina the presence of four alien terrestrial slugs from 
the families Limacidae, Agriolimacidae, Arionidae and Philomycidae, on the basis of morphologic and molecular-genetic identifications and, wherever possible, to make inferences about the origins of those species and the possible consequences of their introductions.

\section{MATERIALS AND METHODS}

Specimen collections and morphology-based identifications

Malacological collections from the Museo de La Plata (MLP), the Museo Argentino de Ciencias Naturales (MACN-In), the Instituto Fundación Miguel Lillo (IFML), and the United States
Department of Agriculture (USDA) were surveyed (Table 1). The specimens chosen (Limacidae $N=43$; Agriolimacidae $N=62$; Arionidae $N=14$; Philomycidae $N=12$ ) were dissected under a stereomicroscope and identified mainly on the basis of the reproductive system and/or the external morphology. Adult specimens, properly relaxed, were measured to establish a length range.

DNA extraction, polymerase chain reaction (PCR) amplification, and genetic sequencing

Total DNA was extracted from $2 \mathrm{~mm}^{3}$ samples from the foot of each dissected slug. The tissue was rinsed in distilled

Table 1. Material examined from slugs from Argentina. IFML, Instituto Fundación Miguel Lillo; MACN-In, Museo Argentino de Ciencias Naturales; MLP, Museo de La Plata; N, number of specimens; USDA, United States Department of Agriculture.

\begin{tabular}{|c|c|c|c|c|c|c|}
\hline Family & Province & Site & Date & Collection & $N$ & Coordinates \\
\hline \multirow[t]{6}{*}{ Limacidae } & Tucumán & San Miquel & 1962 & IFML 604 & 28 & $26^{\circ} 49^{\prime} \mathrm{S}, 65^{\circ} 12^{\prime} \mathrm{W}$ \\
\hline & Chubut & Lago Puelo Nat. Park & 2003 & IFML 14431 & 4 & $42^{\circ} 05^{\prime} \mathrm{S}, 71^{\circ} 36^{\prime} \mathrm{W}$ \\
\hline & Buenos Aires & Sierras Bayas & 1924 & MACN-In 14602 & 5 & $36^{\circ} 56^{\prime} \mathrm{S}, 60^{\circ} 09^{\prime} \mathrm{W}$ \\
\hline & & La Plata & 2012 & MLP 13636 & 8 & $34^{\circ} 55^{\prime} \mathrm{S}, 57^{\circ} 55^{\prime} \mathrm{W}$ \\
\hline & Río Negro & El Bolsón & 2004 & MACN-In 36158 & 1 & $51^{\circ} 58^{\prime} \mathrm{S}, 71^{\circ} 32^{\prime} \mathrm{W}$ \\
\hline & Neuquén & Neuquén & 2004 & MACN-In 36162 & 1 & $38^{\circ} 56^{\prime} \mathrm{S}, 68^{\circ} 03^{\prime} \mathrm{W}$ \\
\hline \multirow[t]{9}{*}{ Agriolimacidae } & Río Negro & El Bolsón & 2004 & $\begin{array}{l}\text { MACN-In } 36157 \\
\text { MACN-In 36158/1 }\end{array}$ & 2 & $51^{\circ} 58^{\prime} \mathrm{S}, 71^{\circ} 32^{\prime} \mathrm{W}$ \\
\hline & & Dina Huapi & 2004 & $\begin{array}{l}\text { MACN-In } 36167 \\
\text { MACN-In 36168/1 }\end{array}$ & 4 & $41^{\circ} 05^{\prime} \mathrm{S}, 71^{\circ} 10^{\prime} \mathrm{W}$ \\
\hline & & San Carlos de Bariloche & 2004 & $\begin{array}{l}\text { MACN-In 36173 } \\
\text { MACN-In 36179-80 } \\
\text { MACN-In 36182-83 } \\
\text { MACN-In 36186/2 } \\
\text { MACN-In 36188-92 }\end{array}$ & 33 & $41^{\circ} 08^{\prime} \mathrm{S}, 71^{\circ} 18^{\prime} \mathrm{W}$ \\
\hline & & Cerro Otto & 2004 & MACN-In 36177 & 4 & $41^{\circ} 08^{\prime} \mathrm{S}, 71^{\circ} 19^{\prime} \mathrm{W}$ \\
\hline & & Nahuel Malal & 2004 & MACN-In 36176 & 2 & $41^{\circ} 06^{\prime} \mathrm{S}, 71^{\circ} 26^{\prime} \mathrm{W}$ \\
\hline & & Manantial & 2004 & MACN-In 36181/1 & 2 & $40^{\circ} 40^{\prime} \mathrm{S}, 71^{\circ} 37^{\prime} \mathrm{W}$ \\
\hline & Neuquén & Neuquén & 2004 & MACN-In 36162 & 1 & $38^{\circ} 56^{\prime} \mathrm{S}, 68^{\circ} 03^{\prime} \mathrm{W}$ \\
\hline & & Isla Victoria & 2004 & MACN-In 36164 & 12 & $40^{\circ} 58^{\prime} \mathrm{S}, 71^{\circ} 31^{\prime} \mathrm{W}$ \\
\hline & & Villa La Angostura & 2004 & MACN-In 36169 & 4 & $40^{\circ} 45^{\prime} \mathrm{S}, 71^{\circ} 38^{\prime} \mathrm{W}$ \\
\hline \multirow[t]{6}{*}{ Arionidae } & Chubut & Los Alerces Nat. Park & 2010 & $\begin{array}{l}\text { MLP } 13405 \\
\text { IFML } 15569\end{array}$ & 12 & $42^{\circ} 36^{\prime} \mathrm{S}, 71^{\circ} 38^{\prime} \mathrm{W}$ \\
\hline & & Los Alerces Nat. Park & 2003 & $\begin{array}{l}\text { MLP } 13404 \\
\text { IFML } 15463\end{array}$ & 5 & $42^{\circ} 44^{\prime} \mathrm{S}, 71^{\circ} 44^{\prime} \mathrm{W}$ \\
\hline & & Lago Puelo Nat. Park & 2003 & $\begin{array}{l}\text { IFML } 15449 \\
\text { IFML } 15566\end{array}$ & 13 & $42^{\circ} 05^{\prime} \mathrm{S}, 71^{\circ} 36^{\prime} \mathrm{W}$ \\
\hline & & Lago Puelo Nat. Park & 2004 & MACN-In 36184 & 2 & $42^{\circ} 05^{\prime} \mathrm{S}, 71^{\circ} 37^{\prime} \mathrm{W}$ \\
\hline & Río Negro & Guillelmo lake & 2010 & IFML $15568 \mathrm{~A}$ & 3 & $41^{\circ} 21^{\prime} \mathrm{S}, 71^{\circ} 29^{\prime} \mathrm{W}$ \\
\hline & & San Carlos de Bariloche & 2004 & $\begin{array}{l}\text { MACN-In } 36170 \\
\text { MACN-In 36186/1 }\end{array}$ & 4 & $41^{\circ} 05^{\prime} \mathrm{S}, 71^{\circ} 27^{\prime} \mathrm{W}$ \\
\hline \multirow[t]{5}{*}{ Philomycidae } & Misiones & Iguazú Nat. Park & 2009 & MLP 13402 & 3 & $25^{\circ} 41^{\prime} \mathrm{S}, 54^{\circ} 27^{\prime} \mathrm{W}$ \\
\hline & & Tabay Fall & 2009 & MLP 13403 & 5 & $27^{\circ} 00^{\prime} \mathrm{S}, 55^{\circ} 11^{\prime} \mathrm{W}$ \\
\hline & & Puerto Iguazú & 2011 & IFMLP $15570 \mathrm{~A}$ & 1 & $25^{\circ} 35^{\prime} \mathrm{S}, 54^{\circ} 34^{\prime} \mathrm{W}$ \\
\hline & Tucumán & San Miguel & 1999 & IFML $15571 \mathrm{~A}$ & 1 & $26^{\circ} 48^{\prime} \mathrm{S}, 65^{\circ} 17^{\prime} \mathrm{W}$ \\
\hline & Brazil & Foz do Iguaçu & 2011 & USDA 110442 & 2 & $25^{\circ} 34^{\prime} \mathrm{S}, 54^{\circ} 34^{\prime} \mathrm{W}$ \\
\hline
\end{tabular}


water, ground in $100 \mathrm{mM}$ EDTA and $20 \mathrm{mM}$ Tris, and digested overnight in CTAB buffer containing proteinase K. DNA was purified by a threefold extraction with chloroform-isoamyl alcohol (24:1) followed by precipitation with isopropanol. The DNA was then resuspended in TE buffer. A 655 bp fragment of the gene encoding the mitochondrial cytochrome $c$ oxidase subunit I (COI) was amplified by means of the primers of Folmer et al. (1994).

Amplification was performed in a final volume of $50 \mu \mathrm{l}$ containing: $50-100 \mathrm{ng}$ of template DNA, $0.1 \mu \mathrm{M}$ of each primer, 1X PCR buffer, $50 \mu \mathrm{M}$ dNTPs, $2.5 \mathrm{mM} \mathrm{MgCl}_{2}$, and 1.2 U Platinum Taq polymerase (Invitrogen, Brazil). The thermocycling sequence consisted of $3 \mathrm{~min}$ at $94^{\circ} \mathrm{C} ; 5$ cycles of $30 \mathrm{~s}$ at $94{ }^{\circ} \mathrm{C} ; 40 \mathrm{~s}$ at $45^{\circ} \mathrm{C} ; 1 \mathrm{~min}$ at $72{ }^{\circ} \mathrm{C}$; followed by 35 cycles of 30 s at $94{ }^{\circ} \mathrm{C} ; 40 \mathrm{~s}$ at $51{ }^{\circ} \mathrm{C} ; 1 \mathrm{~min}$ at $72{ }^{\circ} \mathrm{C}$; with a final extension for $10 \mathrm{~min}$ at $72^{\circ} \mathrm{C}$. After purification of the PCR products by electrophoresis in $1.5 \%(\mathrm{w} / \mathrm{v})$ agarose gels through the use of a Zymoclean ${ }^{\mathrm{TM}}$ Gel DNA Recovery Kit (Zymo Research, Orange, California), both DNA strands were sequenced (Macrogen Inc., Seoul, Korea). The resulting sequences were trimmed to remove the primers, and the consensus sequences of the individuals were compared to reference sequences in GenBank through the use of the BLASTN algorithm (Altschul et al. 1990) to identify similarities.

\section{Phylogenetic analyses}

Phylogenetic analyses were conducted in order to confirm the morphology-based identification of the specimens found in Argentina and to make inferences on the source location whenever that identification was possible. For the Agriolimacidae we used the COI sequences of almost all the species represented in Reise et al. (2011) (Table 2). For the Arionidae, we analyzed the COI sequences available in GenBank mainly for the Arion Férussac, 1819 species, those being reported in the literature as either invasive or potentially invasive (McDonnell et al. 2009, Thomas et al. 2010) (Table 3). For the Philomycidae, we conducted the phylogenetic analyses with the COI sequences for only Meghimatium pictum (Stolyczka, 1873) since we counted on a large number of available sequences for that species from various locations

Table 2. Information on the specimens used in the phylogenetic reconstruction of Deroceras species. ${ }^{\star}$ GenBank unpublished sequences: the sequence author and submission year are indicated.

\begin{tabular}{|c|c|c|c|}
\hline Taxon & GenBank \# & Country & Reference \\
\hline Arion distinctus Mabille, 1868 & EF128218 & Taiwan & Tsai and Wu 2008 \\
\hline Pallifera dorsalis (A. Binney, 1842) & FJ896618 & U.S.A. & Tsai et al. 2011 \\
\hline Philomycus carolinianus (Bosc, 1802) & EF128221 & U.S.A. & Tsai et al. 2011 \\
\hline Megapallifera ragsdalei (Webb, 1950) & EF128220 & U.S.A. & Tsai and Wu 2008 \\
\hline \multirow[t]{6}{*}{ Deroceras invadens } & FJ358222 & South Africa & Reise et al. 2011 \\
\hline & JN248295 & Germany & Reise et al. 2011 \\
\hline & JN248296 & United Kingdom & Reise et al. 2011 \\
\hline & JN248297 & Canada & Reise et al. 2011 \\
\hline & JN248298-300 & Italy & Reise et al. 2011 \\
\hline & JQ743070 & Argentina & This work \\
\hline \multirow[t]{3}{*}{ Deroceras laeve } & AF239733 & U.S.A. & Reise et al. 2011 \\
\hline & EF128217 & Taiwan & Tsai and Wu 2008 \\
\hline & HM584699 & - & Reise et al. 2011 \\
\hline \multirow[t]{3}{*}{ Deroceras panormitanum } & JN248304-306 & Italy & Reise et al. 2011 \\
\hline & JN248307-311 & Malta & Reise et al. 2011 \\
\hline & JN248312-313 & Italy & Reise et al. 2011 \\
\hline \multirow[t]{3}{*}{ Deroceras reticulatum } & AF239734 & U.S.A. & Reise et al. 2011 \\
\hline & AM259702-703 & United Kingdom & Reise et al. 2011 \\
\hline & FJ481179 & - & Reise et al. 2011 \\
\hline
\end{tabular}


Table 3. Information on the specimens used in the phylogenetic reconstruction of Arion species. ${ }^{\star}$ GenBank unpublished sequences: the sequence author and submission year are indicated.

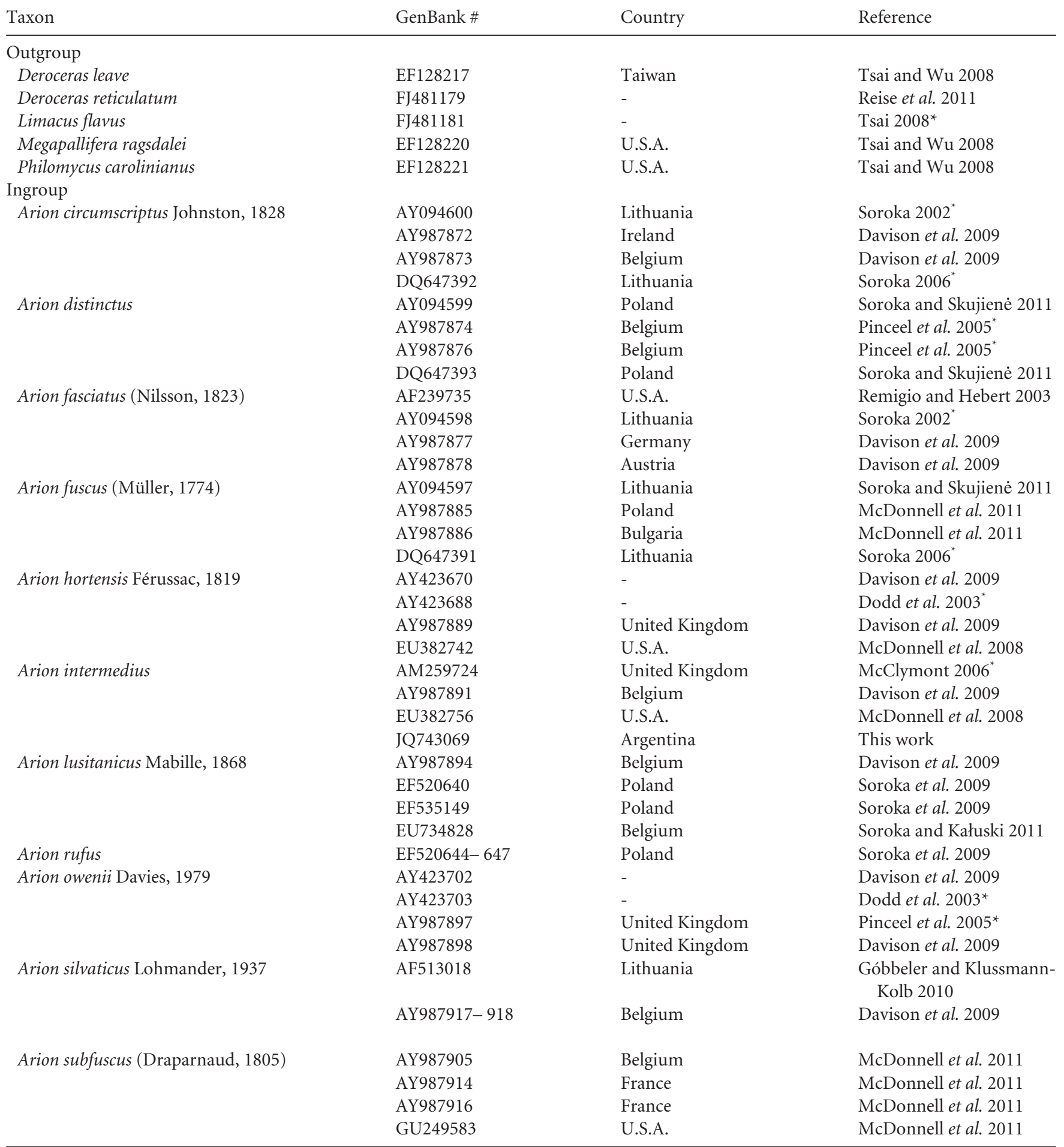


cited in Gomes et al. (2011) and Tsai et al. (2011) (Table 4). Finally, phylogenetic analyses were not possible for the Limacidae because few sequences were available in GenBank, with the molecular identification of this species based only on the BLASTN algorithm.

In all instances, the phylogenetic analyses were carried out as follows: the sequence alignment was performed with the Clustal X 2.0.12 software (Larkin et al. 2007), optimized by visual inspection, and edited with a word processor. The total lengths of the matrices analyzed were $534 \mathrm{bp}$ for the Limacidae, 552 bp for the Arionidae, and 654 bp for the Philomycidae. The data were subjected to four different phylogenetic analyses by the methods of Neighbor-Joining (NJ), maximum parsimony (MP), maximum likelihood (ML), and Bayesian inference (BI). The NJ analysis was conducted with MEGA 5.05 software (Tamura et al. 2011) through the use of the maximum-composite-likelihood option for computing evolutionary distances (Tamura et al. 2004). The MP analysis was carried out with the PAUP ${ }^{\star} 4.0 \mathrm{~b} 10$ software (Swofford 2002), through the use of heuristic search, characters equally

Table 4. Information on the specimens used in the phylogenetic reconstruction of Meghimatium pictum. CMS-DPE, Superintendência de Controle de Endemias do Estado de São Paulo, Brazil; ESRI-MOL, Endemic Species Research Institute, Taiwan; MLP, Museo de La Plata, Argentina; MZSP, Museu de Zoologia da Universidade de São Paulo, Brazil; USDA, United States Department of Agriculture, U.S.A. ${ }^{*}$ GenBank unpublished sequences: the sequence author and submission year are indicated.

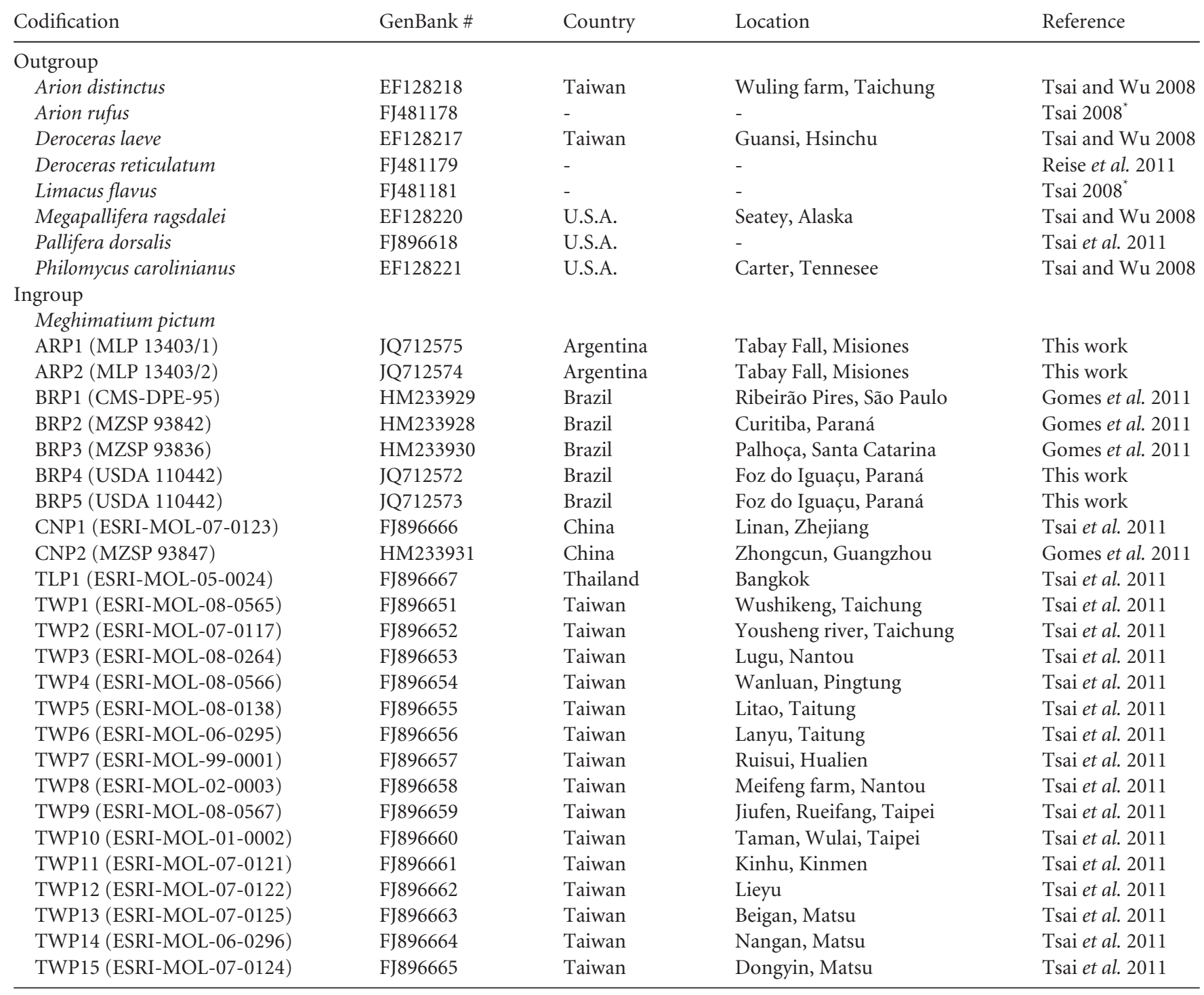


weighted, tree bisection and reconnection branch-swapping and 10 random stepwise additions. The ML inference was performed by means of the PhyML program (Guindon and Gascuel 2003) available at the public Phylemon2 webserver (http://phylemon.bioinfo.cipf.es; Sánchez et al. 2011). The optimal model of nucleotide substitution was evaluated by the likelihood-ratio test and selected by means of the corrected Akaike Information Criterion with the Jmodeltest 0.1.1 software (Posada 2008). The HKY+I+G (for Limacidae), the TIM2 $+\mathrm{I}+\mathrm{G}$ (for Arionidae), and the GTR $+\mathrm{I}+\mathrm{G}$ (for Phylomicidae) substitution models were used as evolutionary paradigms. The statistical support for the resulting phylogenies were assessed by bootstrapping with either 1,000 (NJ, MP) or 100 (ML) replicates (Felsenstein 1985). The BI was carried out with the Mr. Bayes 3.1.2 software (Ronquist and Huelsenbeck 2003). Two runs were performed simultaneously with 4 Markov chains that went for 1,000,000 generations, sampling every 100 generations. The first 10,000 generations of each run were discarded as burnin, and the remaining 18,000 trees were used to estimate posterior probabilities. All the trees were edited with the TreeGraph 2 software (Stöver and Müller 2010).

\section{RESULTS}

\section{Family LIMACIDAE Lamarck, 1801}

The adult specimens had a mean total length of 27.21 $\mathrm{mm}(N=13 ; S D=5.24$; range $=20.7-39.5 \mathrm{~mm})$, with an illdefined keel at the hind end. The external morphology and reproductive system of the dissected adult specimens were consistent with descriptions by Castillejos and Garrido (1996) for Lehmannia valentiana (Férussac, 1823). Specimens from IFML 14431 were identified only by external morphology. Body color of slugs varied from chestnut or auburn to yellowish gray, with two or three black longitudinal bands on the mantle shield and only two on the rest of the body, finalizing in the posterior end. The central band on the mantle shield was diffuse in some cases. Pneumostome was on the right posterior part of mantle. The specimens had been found in urban and protected zones (e.g., Lago Puelo National Park). Lehmannia valentiana has a widespread distribution in Argentina (Fig. 1), and specimens were recorded together with other native and exotic gastropods (e.g., Deroceras reticulatum and Limacus flavus in La Plata city). The molecular data confirmed the morphology-based identification. The BLASTN search results, with the obtained partial COI sequence as the query sequence (Gen Bank JX117876, 655 bp), showed top-ranking scores and a $99 \%$ sequence identity with the only two $554 \mathrm{bp}$ reference COI sequences available in the GenBank nucleotide database (AM259710 and AM259711).

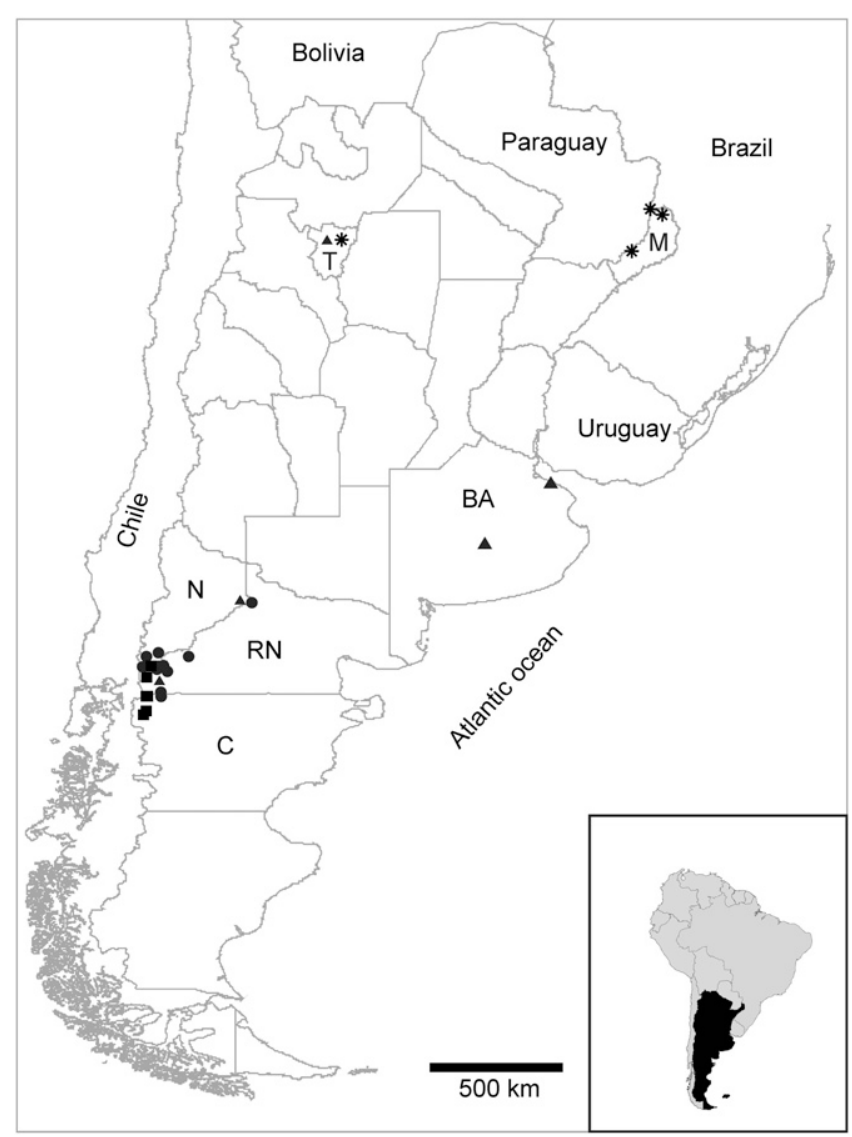

Figure 1. Distribution of new exotic slugs recorded in Argentina. $\mathbf{\Delta}$ : Lehmannia valentiana; 0 : Deroceras invadens; $\mathbf{\square}$ : Arion intermedius; *: Meghimatium pictum. Provinces: BA, Buenos Aires; C, Chubut; M, Misiones; N, Neuquén; RN, Río Negro; T, Tucumán.

\section{Family AGRIOLIMACIDAE Wagner, 1935}

The length of the adult specimens was in general around $12.74 \mathrm{~mm}(N=51 ; S D=1.38$; range $=9.5-16.4 \mathrm{~mm})$. The external morphology and reproductive system of the dissected specimens $(N=62)$ were consistent with descriptions by Reise et al. (2011) for Deroceras invadens Reise et al., 2011. This species has been recorded in both urban and protected areas (e.g., Nahuel Huapi and Arrayanes National Parks) (Fig. 1). The identification of the Agriolimacidae specimen analyzed from Argentina based on molecular analysis confirmed its specific identity as $D$. invadens. The trees obtained by different methods indicated a similar topology that was in agreement with Reise et al. (2011; Fig. 2 cf. the MP and BI trees). In all instances, this specimen from Argentina belonged to the $D$. invadens clade, which assignment was highly supported $(\mathrm{NJ}=100, \mathrm{MP}=98, \mathrm{ML}=100, \mathrm{BI}=$ 1 ), and was furthermore classified in a subgroup inside this clade $(\mathrm{NJ}=87, \mathrm{MP}=93, \mathrm{ML}=84, \mathrm{BI}=0.85)$ one that included sequences from several parts of the world (i.e., Canada, England, France, Germany, South Africa and U.S.A). 

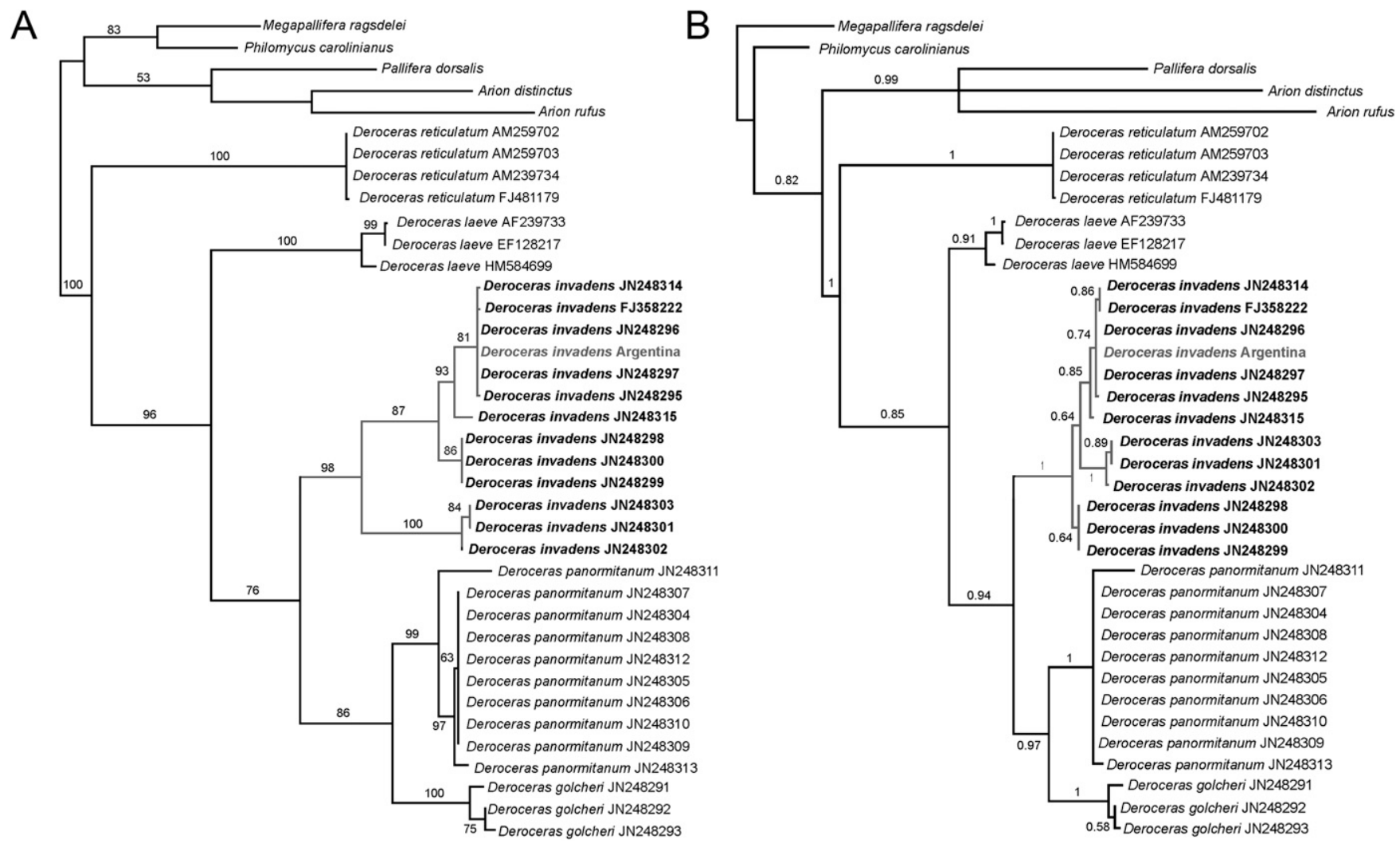

Figure 2. Phylogenetic trees of several Deroceras species based on 534 nucleotides of the partial COI gene. A, The most parsimonious tree (179 parsimony-informative characters, total length $=519, \mathrm{CI}=0.5934, \mathrm{RI}=0.8252$ and, $\mathrm{RC}=0.4897$ ). B, Bayesian consensus tree. The support values: bootstrap values (MP) and posterior probabilities (BI) are shown on the branches. References to the sequences are given in Table 2.

\section{Family ARIONIDAE Gray, 1840}

The specimens had a mean of $10.07 \mathrm{~mm}$ of total length $(N=3 ; S D=0.74$; range $=9.5-10.9 \mathrm{~mm})$. The external morphology and reproductive system of the dissected adult specimens were consistent with the Barker's descriptions (1999) for Arion intermedius Normand, 1852. Specimens from IFML 15449, 15566, 15568 (Table 1) were identified by external morphology. General coloration was golden yellow in most of the collected specimens, without lateral or central bands; ommatophores were dark brown; the mantle was oval with pneumostome on the right side in the antemedial portion; the posterior body section was rounded without keel. The slugs were collected under woodpiles or sheltering under rocks, in synanthropically disturbed locations, such as the service areas of Lago Puelo National Park, and the camping areas in Los Alerces National Park. The identification of the Arionidae specimen (MLP 13405) analyzed by moleculargenetic sequencing confirmed its specific identity as A. intermedius. Different phylogenetic analyses gave very similar topological organization for the NJ, MP, and ML trees and minor differences in the BI-tree organization (Fig. $3 \mathrm{cf}$. the $\mathrm{MP}$ and $\mathrm{BI}$ trees). The specimen from Argentina was placed within the highly supported $A$. intermedius group $(\mathrm{NJ}=100$, $\mathrm{MP}=100, \mathrm{ML}=100, \mathrm{BI}=1$ ).

\section{Family PHILOMYCIDAE Gray, 1847}

Only the specimen from Puerto Iguazú was sexually mature (total length $=50 \mathrm{~mm}$ ). The morphology of its reproductive system and external morphology coincided with descriptions by Tsai et al. (2005) and Gomes et al. (2011) for Meghimatium pictum (Stolyczka, 1873). Specimens from IFML $15570 \mathrm{~A}$ and MLP 13402 (Table 1) were identified by external morphology, which had an opaque beige background color of mantle, with two dark brown to black lateral stripes, and one medial stripe, often lighter than the lateral ones. This species was found in sites ranging from highly anthropically disturbed (in the Misiones and Tucumán provinces) to undisturbed areas (Iguazú National Park; Fig. 1, Table 1). The identification of Philomycidae specimens by DNA-data analysis confirmed their specific identity as M. pictum (MLP 13403 and USDA 110442; Table 1). The sequences obtained were identical and larger $(655 \mathrm{bp})$ than previously reported for the species in South America (Gomes et al. 2011). All four phylogenetic approaches provided similar results and indicated a topology 
A

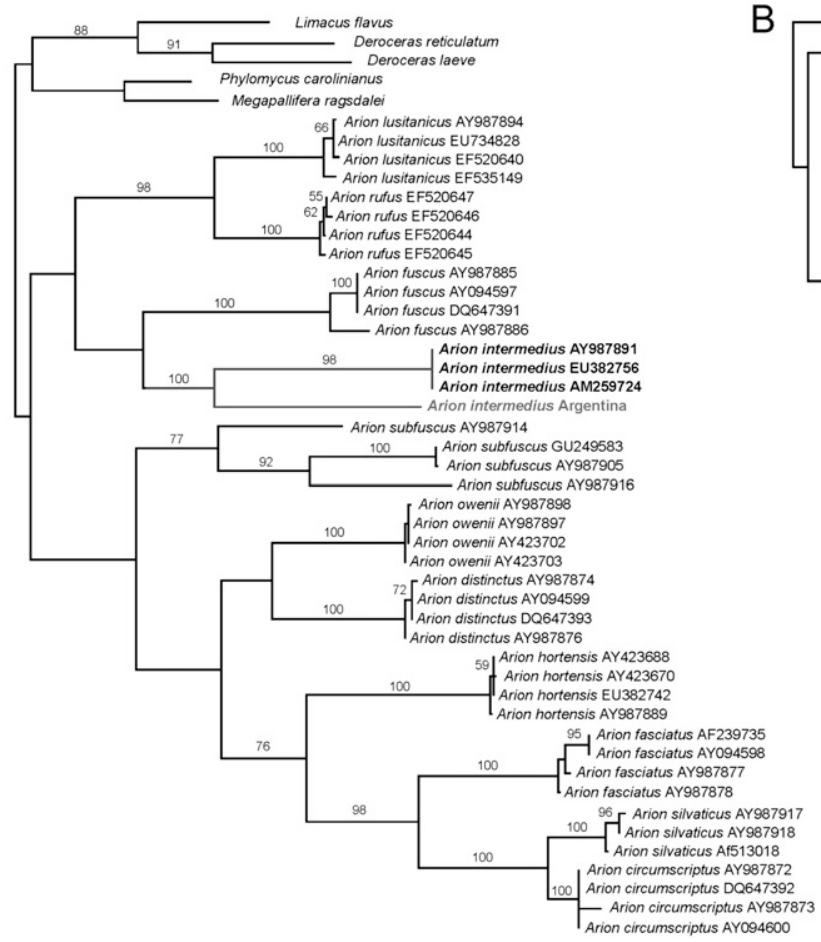

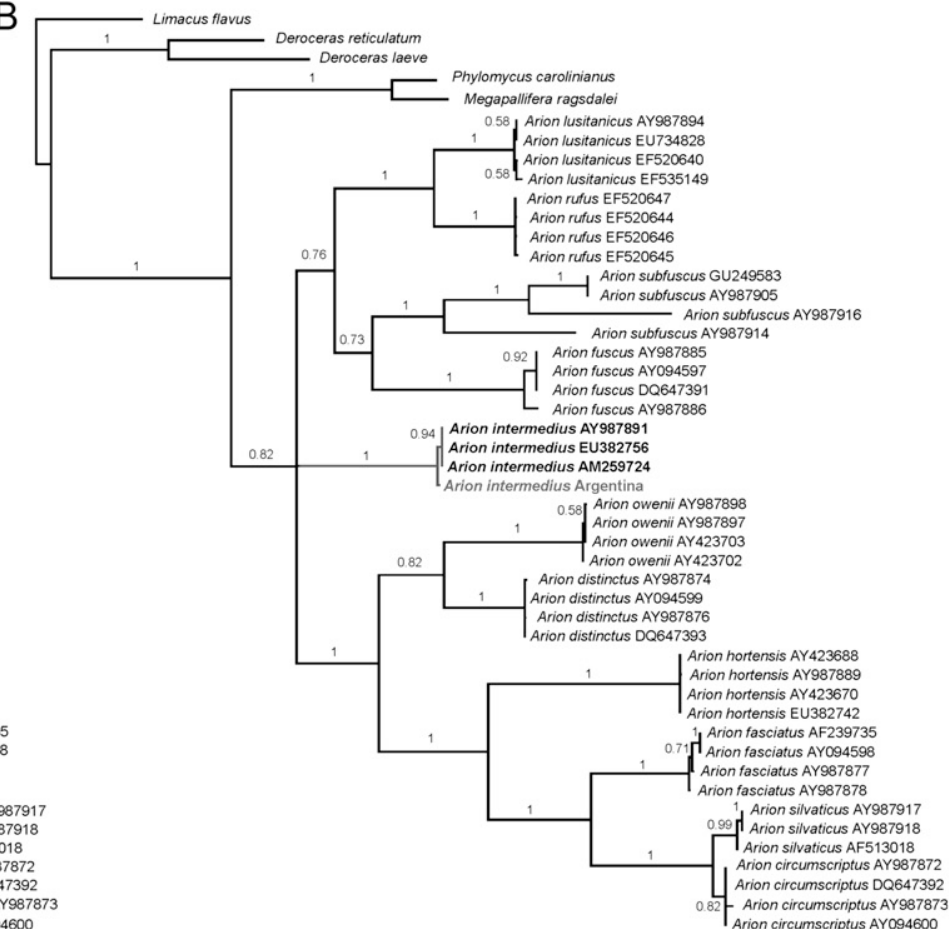

Figure 3. Phylogenetic trees of several invasive or potentially invasive Arion species in South America based on 552 nucleotides of the partial COI gene. A, One of the two most parsimonious trees (229 parsimony-informative characters, total length $=1074, \mathrm{CI}=0.4181, \mathrm{RI}=0.8085$ and, $\mathrm{RC}=0.3380)$. B, Bayesian consensus tree. The support values: bootstrap values $(\mathrm{MP})$ and posterior probabilities (BI) are shown on the branches. References to the sequences are given in Table 3.

in agreement with Tsai et al. (2011; Fig. 4, cf. the MP and BI trees). In all instances, three groups were identified for $M$. pictum: Group $1(\mathrm{NJ}=81, \mathrm{MP}=86, \mathrm{ML}=88, \mathrm{BI}=0.55)$ was geographically restricted to Taiwan Island (TWP1, TWP2, TWP3, TWP5, TWP6, TWP7, TWP8, TWP9 and TWP 10); Group $2(\mathrm{NJ}=100, \mathrm{MP}=100, \mathrm{ML}=100, \mathrm{BI}=1)$ comprised M. pictum from Kinmen (TWP11) and Lieyu (TWP12) Islands as well as the South-American specimens (BRP1, BRP2, BRP3, BRP4, BRP5, ARP1 and ARP2) for which only a single haplotype was found. One sequence from southern Taiwan Island (TWP4) and a sequence from continental China (CNP2) were also found within Group 2. Finally, Group $3(\mathrm{NJ}=$ 99, $\mathrm{MP}=91, \mathrm{ML}=100, \mathrm{BI}=0.81)$ included sequences from continental China (CNP1), Thailand (TLP1) and Matsu Island (i.e., TWP13, TWP14, TWP15).

\section{DISCUSSION}

The present study revealed the existence of established populations of four exotic slugs in Argentina. The taxonomic identification of the alien species reported here is based on anatomical studies in addition to sequences of COI gene and constitutes the first report of the presence of these species, all four of which have already shown an invasive behavior in several South American countries. Deroceras panormitanum (Lessona and Pollonera, 1882) and Lehmannia valentianaboth native of Europe- had been previously recorded for Chile and Colombia, while L. valentiana had also been reported in Brazil and Peru (Rumi et al. 2010). Based on anatomical and molecular evidence Reise et al. (2011) had split D. panormitanum into several species, including D. panormitanum s.s., as well as Deroceras invadens, that latter as the single successful invader worldwide. According to this new taxonomic arrangement, the classification of $D$. panormitanum remains restricted to only the area where was originally described (i.e., Malta and Sicily). Arion intermedius, a typical European Arionidae, has already been recorded in Chile and Colombia (Hausdorf 2002, Letellier et al. 2003, Cádiz and Gallardo 2007). Meghimatium pictum, a native from eastern and southern Asia, had recently been reported as an alien species in southern Brazil, with that record being the first one of the genus in South America (Gomes et al. 2011).

Lehmannia valentiana is the species with the oldest occurrence records in Argentina in comparison to the other three reported here, with data as early as 1924 (Buenos Aires 

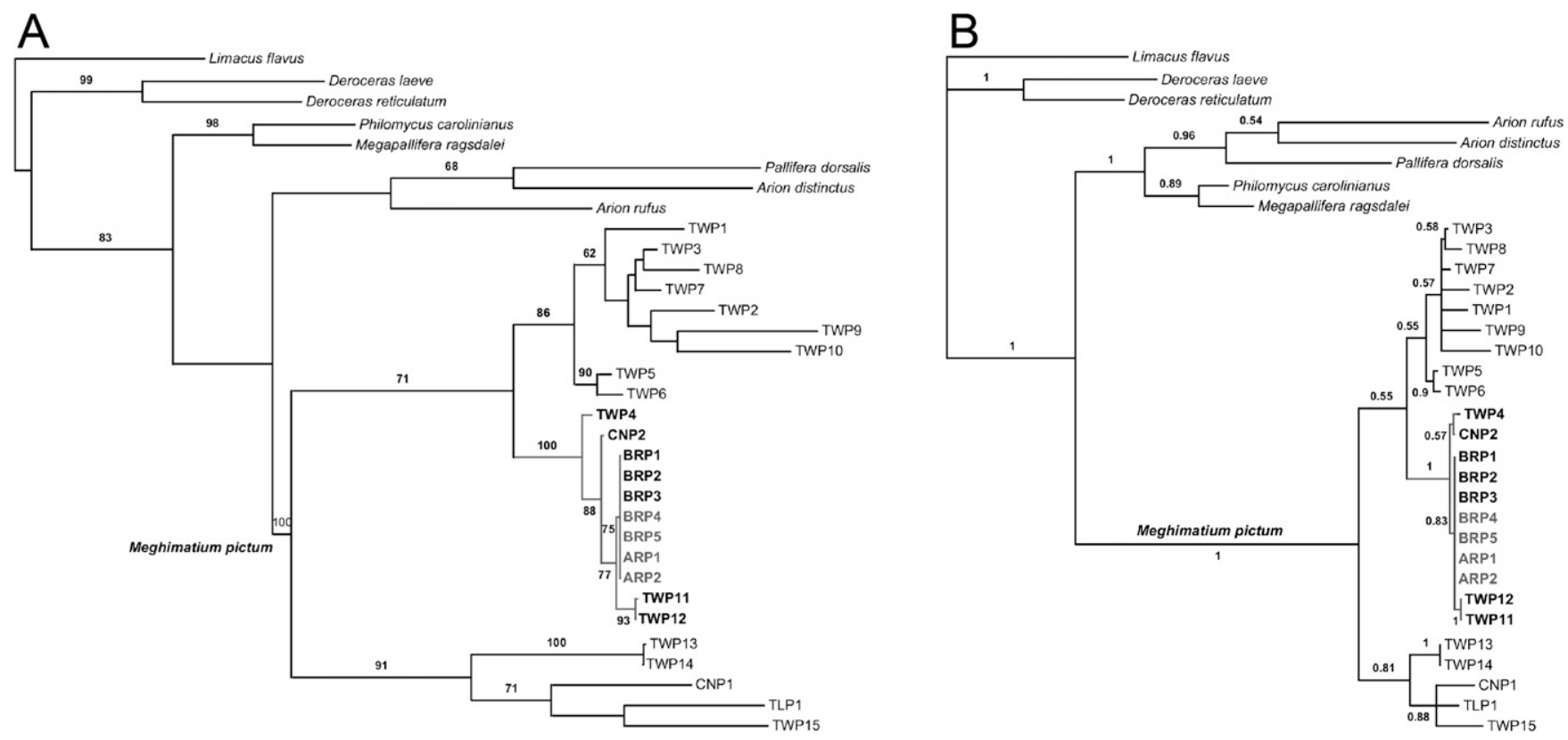

Figure 4. Phylogenetic reconstruction of Meghimatium pictum, based on 654 nucleotides of the partial COI gene. A, One of the six most parsimonious trees (245 parsimony-informative characters, total length $=987, \mathrm{CI}=0.464, \mathrm{RI}=0.6399$ and, $\mathrm{RC}=0.2969$ ). B, Bayesian consensus tree. The support values: bootstrap values (MP) and posterior probabilities (BI) are shown on the branches. References to the sequences are given in Table 4.

province, MACN-In 14602) and 1962 (Tucumán province, IFML 604). To determine when and how this species was introduced into the country, however, is difficult because the molecular information at hand was not enough to shed any light on the area of origin of the species. Lehmannia valentiana could be considered as an established species, with an incipient invasive behavior since specimens have been recorded in remote sites (in both urban and protected areas), feeding on ornamental plants. In other countries, this species is considered to be a greenhouse pest, damaging orchid flowers and ornamental plants (Chichester and Getz 1969, South 1992, Ester et al. 2003).

Deroceras invadens was recorded in southern Argentina; but inferences about the site of the species' introduction were not possible because the sequence from Argentina grouped into a clade that included samples from diverse geographical origins (e.g., Canada, U.S.A., Germany, South Africa), thus indicating that the species had already been widely distributed worldwide. The specimens examined were from several towns of southern Argentina, a distribution that suggested the species had acquired an invasive behavior. The probable pathway for the introduction of $D$. invadens into Argentina could be related to commerce, as has been reported in the United States (Meissner et al. 2009). Deroceras invadens feeds on a great variety of plants and organic material in decomposition and is known to be a pest in pastures, gardens and agricultural fields (Barker 1999). Moreover, this slug species is identified as an intermediate host for the nematode Gallegostrongylus australis Spratt, Haycock and Walter, 2001 (Spratt et al. 2001), which species parasitizes rodent lungs, causing mild pathologic changes.

We could neither clarify the source location nor assign a precise date of introduction for the specimens of Arion intermedius studied. Cádiz and Gallardo (2007) had reported this species for the first time in neighboring Chile, but the date cited could be considered controversial because Letelier $e t a l$. (2003) had recorded many specimens of A. intermedius deposited into National Museum of Natural History of Chile (but with no collection number) from southern Chile. We could nevertheless, conclude that populations of $A$. intermedius had been living in Argentina since at least 2003, the year when they were first collected (Table 1). This species can be considered to be established in Argentina since live specimens had also been found at the same locations seven years later, during the summer 2010 (Table 1). The pathway of introduction of the species into southern Argentina, however, remains unclear. Cádiz and Gallardo (2007) could not establish the introduction pathway into Chile, although they concluded that human accidental transport was the probable cause since species of that genus were being recovered from U.S. seaports on limestone, machinery and rocks (Meissner et al. 2009). Arion intermedius exhibits polyphagous or phytophagous 
feeding habits and a predominant autofecundation, a strategy that increases its invasive capabilities (Wiktor et al. 2000, Reise et al. 2001). They are known to have a high capacity for penetrating undisturbed native forest, more so than any other type of exotic slug species (Hausdorf 2002, Cadiz and Gallardo 2007). In Argentina, occurrences of the species were recorded within national park areas, far away from urban environments. Within the Arionidae, the genus Arion Férussac, 1819 is recognized by international organizations concerned with pest control, such as the Eastern Region Cooperative Agricultural Pest Survey, as potentially damaging for agriculture (Cádiz and Gallardo 2007). Specimens could also act as intermediate hosts for nematodes such as Filaroides martis (Werner, 1783), a parasite that affects the respiratory tract of mammals (Grewal et al. 2003). In both the most parsimonious tree and the Bayesian consensus tree (Fig. 3), the Arion species analyzed grouped in a single clade, suggesting that phylogenetic analysis is as reliable a tool as the morphology in corroborating the identity of the different invasive members of the Arion genus.

The introduction of Meghimatium pictum into South America, and particularly into Brazil, was suggested to have been accidental through agricultural products in the 1990s, coinciding with the beginning of trade between China and Brazil in order to boost the production of mushrooms in the latter country (Gomes et al. 2011). On the basis of position of the South-American samples in all the topologies obtained in our phylogenetic reconstructions, we suggest that the origin of the South-American invasive lineage might be located in a region west of the Strait of Taiwan, either along the coast of China or within the islands close to that coast such as the Taiwanese Kinmen and Lieyu Islands. Currently, M. pictum can be found in several states of Brazil (Paraná, Santa Catarina and Río Grande do Sul) bordering northeast Argentina and also in São Paulo State (Gomes et al. 2011). Occurrences of this species in the Misiones province of Argentina suggest that the introduction pathway into Argentina could possibly be linked either to an active dispersion of the slug from Brazil and/or to the commerce of flora between those aforementioned Brazilian areas and Argentina. That we recorded one specimen of $M$. pictum in a garden with orchids collected from the Misiones province plus other plants acquired from nurseries in the Tucumán province supports our hypothesis about the commercial trade as being the principal vector of introduction.

In Brazil, Meghimatium pictum was associated with the attack of plants in private gardens in Santa Catarina (Gomes et al. 2011) and has affected grape vines in Rio Grande do Sul (Baronio et al. 2011). In Argentina, further studies are required to know if incipient grape vines in Misiones province, covering about 50 hectares, are already affected; though, the extent of the invasion could be even worse if the species has reached the western provinces (Mendoza, San Juan, La Rioja and Catamarca) where the $97 \%$ of the domestic production of wine is concentrated. Such a development could have serious implications on the country's national and international wine trade. In the Argentine areas where M. pictum is present, several other gastropods species (both natives and exotics) that can act as intermediate hosts for the zoonotic parasitic nematode Angiostrongylus costaricensis Moreira and Céspedes, 1971 can be found, with the potential risk that M. pictum could likewise begin to act as a new vector. Meghimatium bilineatum (Benson, 1842), a very close species to M. pictum, has furthermore been reported to be a host of Angiostrongylus cantonensis (Cheng, 1935) (Li et al. 2006), another zoonotic parasitic nematode.

We provide here the first report of four new exotic slugs in Argentine territories. Because of the invasive potential of these slug species, the present work provides new COI sequences obtained from morphologically confirmed specimens. We believe that the information contained in this report can help nonspecialists and government authorities quickly identify these species for the purpose of establishing guidelines for the prevention, control, and diffusion of those alien slugs.

\section{ACKNOWLEDGMENTS}

This study was financially supported by National Agency of Scientific Promotion and CONICET (BID-PICT-20080233 and 2008-2042; PIP 2010-0080). The authors would like to thank L. Semenas, Centro Regional Universitario Bariloche (Universidad Nacional del Sur), for the donation of the material from southern Argentina. MGC would like to acknowledge the Argentine National Park Agency, which provided several working permits within the conservation areas, for their support while collecting in southern parks. Finally, the authors are grateful to Dr. Donald F. Haggerty, a retired scientist and native English speaker, for editing the final version of the manuscript.

\section{LITERATURE CITED}

Altschul, S. F., W. Gish, W. Miller, E. W. Myers, and D. J. Lipman. 1990. Basic local alignment search tool. Journal of Molecular Biology 215: 403-410.

Barker, G. M. 1999. Naturalised terrestrial Stylommatophora (Mollusca: Gastropoda). Fauna of New Zealand 38: 1-247.

Baronio, C. A., M. Botton, and S. R. Gomes. 2011. Lesmas terrestres Meghimatium pictum (Stoliczka, 1873) (Philomicidae) e Sarasinula erinacea (Colosi, 1921) (Veronicellidae) (Mollusca, Gastropoda) causando danos em vinhedos na Serra Gaúcha, RS, Brasil. XXII Encontro Brasileiro de Malacologia, Fortaleza, Brasil, 4-8 September 2011. [In Portuguese]. 
Cádiz, F. J. and C. S. Gallardo. 2007. Arion intermedius (Gastropoda: Stylommatophora); first record of this introduced slug in Chile, with notes on its anatomy and natural history. Revista Chilena de Historia Natural 80: 99-108.

Castillejo, J. and C. Garrido. 1996. Las babosas de la familia Limacidae Rafinesque, 1815 (Gastropoda Pulmonata Terrestria nuda) de la Península Ibérica e Islas Baleares. Morfología y distribución. Nova Acta Científica Compostelana (Bioloxía) 6: 131-143. [In Spanish].

Chichester, L. F. and L. L. Getz. 1969. The zoogeography and ecology of arionid and limacid slugs introduced into northeastern North America. Malacologia 7: 313-346.

Cowie, R. H. and D. G. Robinson. 2003. Pathways of introduction of nonindigenous land and freshwater snails and slugs. In: G. Ruiz, and J. T. Carlton, eds., Invasive species: vectors and management strategies. Island Press, Washington, District of Columbia, Pp. 93-122.

Darrigran, G. A. and M. C. Damborenea. 2006. Bio-invasión del mejillón dorado en el continente americano. Editorial de la Universidad Nacional de La Plata, La Plata, Argentina. [In Spanish].

Davison, A., R. L. E. Blackie, and G. P. Scothern. 2009. DNA barcoding of stylommatophoran land snails: a test of existing sequences. Molecular Ecology Resources 9: 1092-1101.

Ester, A., K. van Rozen, and L. P. G. Molendijk. 2003. Field experiments using the rhabditid nematode Phasmarhabditis hermaphrodita or salt as control measures against slugs in green asparagus. Crop Protection 22: 689-695.

Facon, B., J. P. Pointier, M. Glaubrecht, C. Poux, P. Jarne, and P. David. 2003. A molecular phylogeography approach to biological invasions of the New World by parthenogenetic thiarid snails. Molecular Ecology 12: 3027-2039.

Felsenstein, J. 1985. Confidence limits on phylogenies: An approach using the bootstrap. Evolution 39: 783-791.

Folmer, O., M. Back, W. Hoeh, R. Lutz, and R. Vrijenhoek. 1994. DNA primers for amplification of mitochondrial cytochrome c oxidase subunit I from diverse metazoan invertebrates. Molecular Marine Biology and Biotechnology 3: 294-299.

Giberto, D. A., C. S. Bremec, L. Schejter, A. Schiariti, H. Mianzan, and E. M. Acha. 2006. The invasive rapa whelk Rapana venosa (Valenciennes 1846): Status and potential ecological impacts in the Río de la Plata estuary, Argentina-Uruguay. Journal Shellfish of Research 25: 919-924.

Góbbeler, K., and A. Klussmann-Kolb. 2010. The phylogeny of the Acteonoidea (Gastropoda): Molecular systematics and first detailed morphological study of Rictaxis punctocaelatus (Carpenter, 1864). Journal of Molluscan Studies 76: 303-316.

Gomes, S. R., J. B. Picanço, E. Colley, A. I. Agudo-Padrón, E. Nakano, and J. W. Thomé. 2011. A newly introduced and invasive land slug in Brazil: Meghimatium pictum (Gastropoda, Philomycidae) from China. Proceedings of the Academy of Natural Sciences of Philadelphia 16: 87-95.

Grewal, P. S., S. K. Grewal, L. Tan, and B. J. Adams. 2003. Parasitism of molluscs by Nematodes: Types of associations and evolutionary trends. Journal of Nematology 35: 146-156.

Guindon, S. and O. Gascuel. 2003. A simple, fast, and accurate algorithm to estimate large phylogenies by maximum likelihood. Systematic Biology 52: 696-704.
Gutiérrez Gregoric, D. E., V. Núñez, R. E. Vogler, and A. Rumi. 2011. Invasion of the Argentinean Paranense rainforest by the giant african snail Achatina fulica. American Malacological Bulletin 19: 135-137.

Hausdorf, B. 2002. Introduced land snails and slugs in Colombia. Journal of Molluscan Studies 68: 127-131.

Larkin, M. A., G. Blackshields, N. P. Brown, R. Chenna, P. A. McGettigan, H. McWilliam, F. Valentin, I. M. Wallace, A. Wilm, R. Lopez, J. D. Thompson, T. J. Gibson, and D. G. Higgins. 2007. Clustal W and Clustal X version 2.0. Bioinformatics 23: 2947-2948.

Letelier, S., M. A. Vega, A. M. Ramos, and E. Carreño. 2003. Base de datos del Museo Nacional de Historia Natural: Moluscos de Chile. Revista de Biología Tropical 51 (Supplement 3): 33-138. [In Spanish].

Li, L. S., X. N. Zhou, J. X. Lin, Y. Zhang, Y. Z. Chen, R. Y. Zhang, Y. Y. Fang, C. X. Lin, B. J. Chen, and Y. S. Li. 2006. Discovery of six new host species of Angiostrongylus cantonensis and investigation of the epidemic foci in Fujian province. Chinese Journal of Zoonoses 22: 533-537.

Lizarralde, M. S., G. Bailliet, S. Poljak, M. Fasanella, and C. Giulivi. 2008. Assessing genetic variation and population structure of invasive North American beaver (Castor canadensis Kuhl, 1820) in Tierra del Fuego (Argentina). Biological Invasions 10: 673-683.

McDonnell, R. J., T. D. Paine, and M. J. Gormally. 2009. Slugs: A Guide to the Invasive and Native Fauna of California. University of California, Oakland, California.

McDonnell, R. C., T. D. Paine, R. Stouthamer, M. J. Gormally, and J. D. Harwood. 2008. Molecular and morphological evidence for the occurrence of two new species of invasive slugs in Kentucky, Arion intermedius Normand and Arion hortensis Férussac (Arionidae: Stylommatophora). Journal of the Kentucky Academy of Science 69: 117-123.

McDonnell, R. J., P. Rugman-Jones, T. Backeljau, K. Breugelmans, K. Jordaens, R. Stouthamer, T. Paine, and M. J. Gormally. 2011. Molecular identification of the exotic slug Arion subfuscus sensu stricto (Gastropoda: Pulmonata) in California, with comments on the source location of introduced populations. Biological Invasions 13: 61-66.

Meissner, H., A. Lemay, C. Bertone, K. Schwatzburg, L. Ferguson, and L. Newton. 2009. Evaluation of Pathways for Exotic Plant Pest Movement into and Within the Greater Caribbean Region. Caribbean invasive species working group, plant epidemiology and risk analysis laboratory, Center for Plant Health Science and Technology, and U.S. Department of Agriculture, Raleigh, North Carolina.

Miquel, S. E., A. Tablado, and A. Sodor. 2007. Curaduría en la colección nacional de invertebrados de Argentina: Aportes a la biodiversidad y biogeografía de gasterópodos terrestres argentinos. Comunicaciones de la Sociedad Malacológica del Uruguay 9(90): 113-115. [In Spanish].

Mooney, H. A., R. N. Mack, J. A. McNeely, L. Neville, P. J. Schei, and J. Waage. 2005. Invasive Alien Species: A New Synthesis. Island Press, Washington, District of Columbia.

Nentwig, W. 2007. Biological invasions: Why it matters. In: W. Nentwig, ed. Biological invasions. Springer-Verlag, Berlin, Heidelberg, Germany. Pp. 1-9. 
Parent, H. and S. E. Miquel. 1999. Un gasterópodo terrestre del Viejo Mundo, introducido en la Argentina. Physis, Series C, 56(130-131): 59. [In Spanish].

Posada, D. 2008. JModeltest: Phylogenetic model averaging. Molecular Biology and Evolution 25: 1253-1256.

Reise, H., B. Zimdars, K. Jordaens, and T. Backeljau. 2001. First evidence of possible outcrossing in the terrestrial slug Arion intermedius (Gastropoda: Pulmonata). Hereditas 134: 267-270.

Reise, H., J. M. C. Hutchinson, S. Schunack, and B. Schlitt. 2011. Deroceras panormitanum and congeners from Malta and Sicily, with a redescription of the widespread pest slug as Deroceras invadens n. sp. Folia Malacologica 19: 201-223.

Remigio, E. A. and P. N. D. Hebert. 2003. Testing the utility of partial COI sequences for phylogenetic estimates of gastropods relationships. Molecular Phylogenetics and Evolution 29: 641-647.

Ronquist, F. and J. P. Huelsenbeck. 2003. MRBAYES 3: Bayesian phylogenetic inference under mixed models. Bioinformatics 19: 1572-1574.

Rumi, A., J. Sánchez, and N. S. Ferrando. 2010. Theba pisana (Müller, 1774) (Gastropoda, Helicidae) and other alien land molluscs species in Argentina. Biological Invasions 12: 2985-2990.

Sánchez, R., F. Serra, J. Tárraga, I. Medina, J. Carbonell, L. Pulido, A. de María, S. Capella-Gutiérrez, J. Huerta-Cepas, T. Gabaldón, J. Dopazo, and H. Dopazo. 2011. Phylemon 2.0: A suite of webtools for molecular evolution, phylogenetics, phylogenomics and hypotheses testing. Nucleic Acids Research 39: W470W474.

Soroka, M. and T. Kałuski. 2011. Genetic studies on the invasive slug Arion lusitanicus Mabille, 1868 (Gastropoda: Pulmonata) in Poland. Folia Malacologica 19: 259-265.

Soroka, M., J. Kozłowski, A. Wiktor, and T. Kałuski. 2009. Distribution and genetic diversity of the terrestrial slugs Arion lusitanicus Mabille, 1868 and Arion rufus (Linnaeus, 1758) in Poland based on mitochondrial DNA. Folia Biologica (Krakow) 57: 71-81.

Soroka, M., and G. Skujiené. 2011. Species identification of slugs of genus Arion Férussac, 1819 (Mollusca, Pulmonata) on the basis of genetics studies. Ekologija 57: 70-80.

South, A. 1992. Terrestrial Slugs. Biology, Ecology and Control. Chapman \& Hall, London, UK.

Spratt, D. M., P. Haycock, and E. L. Walter. 2001. Life history and pathogenesis of Gallegostrongylus australis (Nematoda: Angiostrongylidae) in Muridae. Parasite 8: 115-125.

Stöver, B. C. and K. F. Müller. 2010. TreeGraph 2: Combining and visualizing evidence from different phylogenetic analyses. BMC Bioinformatics 11: 7. doi:10.1186/1471-2105-11-7.

Swofford, D. L. 2002. PAUP ${ }^{\star}$ Phylogenetic Analysis Using Parsimony ( ${ }^{*}$ and Other Methods). Version 4. Sinauer Associates, Sunderland, Massachusetts.

Tamura, K., M. Nei, and S. Kumar. 2004. Prospects for inferring very large phylogenies by using the neighbor-joining method. Proceedings of the National Academy of Science 101: 11030-11035.

Tamura, K., D. Peterson, N. Peterson, G. Stecher, M. Nei, and S. Kumar. 2011. MEGA5: Molecular evolutionary genetics analysis using maximum likelihood, evolutionary distance, and maximum parsimony methods. Molecular Biology and Evolution 28: 2731-2739.
Thiengo, S. C., F. A. Faraco, N. C. Salgado, R. H. Cowie, and M. A. Fernandez. 2007. Rapid spread of an invasive snail in South America: The giant African snail, Achatina fulica, in Brasil. Biological Invasions 9: 693-702.

Thomas, A. K., R. J. McDonnell, T. D. Paine, and J. D. Harwood. 2010. A Field Guide to the Slugs of Kentucky. Agricultural Experiment Station. University of Kentucky, College of Agriculture, SR103.

Tsai, C. L., H. H. Lin, and S. K. Wu. 2005. Comparison of four philomycid slugs (Gastropoda: Stylommatophora: Philomycidae) of Taiwan. Endemic Species Research 7: 41-49. [In Chinese].

Tsai, C. L., C. C. Lu, and H. W. Kao. 2011. Morphology and molecular phylogeny of the east and southeast Asian Meghimatium slugs (Gastropoda: Pulmonata: Philomycidae) and description of a new species. Zootaxa 2890: 1-19.

Tsai, C. L. and S. K. Wu. 2008. A new Meghimatium slug (Pulmonata: Philomycidae) from Taiwan. Zoological Studies 47: 759-766.

Vitousek, P. M., C. M. D'Antonio, L. L. Loope, and R. Westbrooks. 1996. Biological invasions as global environmental change. American Scientist 84: 468-478.

Wiktor, A., D. N. Chen, and M. Wu. 2000. Stylommatophoran slugs of China (Gastropoda: Pulmonata) Prodromus. Folia Malacologica 8: 3-35.

Submitted: 26 December 2012; accepted: 6 April 2013; final revisions received: 14 June 2013 